\title{
HERMIZ - GAS MONITORING APPLICATION PROGRAMMING INTERFACE
}

Michell Thompson Ferreira Santiago', Francimar Conceição dos Santos², Larissa Vanile Santos Carneiro², Rafael Maia Gadelha², Tiago Jairo Vieira de Almeida², Fabio Santos Mota ${ }^{3}$, Tiara Borges Santiago Ferreira';

'Universidade Cândido Mendes; Campos Rua Anita Peçanha, 100 - Pq. São Caetano - Campos dos Goytacazes/RJ;

${ }^{2}$ Faculdade Metropolitana de Camaçari. Tv. da Avenida Leste; Camaçari/BA;

${ }^{3}$ Universidade do Estado da Bahia - UNEB. Rua Silveira Martins; Salvador/BA

\begin{abstract}
The current situation in which the world finds itself, generates opportunities for improvement including systems that used to be only manual for more characterized digital systems. This article aimed at building an Application Programming Interface for monitoring and controlling gas levels used in health centers. The device was based on the daily experiences of professionals in the field. The technology aims to eliminate the communication gap between health units and minimize problems related to the monitoring of medical gases in the health system and also in the industry, through an internet of things solution, which has a database of synchronized information, making it easy to access by any authorized professional.
\end{abstract}

Keywords: Application Programming Interface; Internet of Things; Medicinal gases.

\section{HERMIZ - INTERFACE DE PROGRAMAÇÃO DE APLICATIVO DE MONITORAMENTO DE GÁS}

Resumo: A situação atual em que o mundo se encontra, gera oportunidades de melhoria incluindo sistemas outrora apenas manual para sistemas digitais mais confiáveis. O presente artigo objetivasse na construção de uma Interface de Programação de Aplicativos para monitoramento e controle de níveis de gases utilizados em centros de saúde. O dispositivo foi baseado nas vivências cotidianas dos profissionais da área. A tecnologia visa eliminar a lacuna de comunicação entre unidades de saúde e minimizar problemas relacionados ao monitoramento de gases medicinais no sistema de saúde e também na indústria, por meio de uma solução de internet das coisas, que possui um banco de dados de informações sincronizadas, tornando-se fácil acesso por qualquer profissional autorizado.

Palavras-chave: Gases Medicinais; Interface de Programação de Aplicativos; Internet das coisas 


\section{INTRODUCTION}

For many years, healthcare professionals have experienced problems when referring patients to healthcare facilities due to the lack of information regarding the levels of hospital gases present in these facilities, and at present this problem was accentuated during the recurrent coronavirus pandemic of the large increase in patients who needed respiratory therapies. Some professionals report that, as there is no electronic monitoring, they refer the patient practically blind, and when they arrive at the health unit, there may be no hospital oxygen cylinders available.

Recently in the city of São Gabriel da Cachoeira in the state of Amazonas the only hospital in the city was full, there are 15 mechanical respirators in the unit, the functioning of the respirators also depends on oxygen cylinders coming from the capital, as the city's oxygen plant is broken and it can only supply two devices. The cylinder stock ran out, employees bought industrial oxygen cylinders in workshops. Although the use is contraindicated for hospital purposes, it has the same composition as medicinal oxygen. Two industrial cylinders were used until a new loading arrived [1].

Currently monitoring is carried out manually in a form, so that the hospital has control of its inventory of hospital gases, with computerization it would make monitoring easier and unifying all information from hospitals.

This article aimed at building an Application Programming Interface for monitoring and controlling gas levels used in health centers. This problem is not only present in the health area, in the industrial sector there are problems due to the lack of ineffective monitoring, as for example it was evidenced in a company that operates in the field of welding during its production process using gas welding there is a high rework rate due to the absence of this type of monitoring in its manufacturing process, in a cell, every 3 days it is estimated a loss of 9 thousand reais, in a year approximately 1 million reais is calculated.

\section{METHODOLOGY}

In view of the accentuated problems with the emergence of the pandemic in the country, an API was developed (Figure 1) to unify the information of the health network so that professionals in the area who are on the front line can refer the patient to a health unit that can accommodate, as well as, allow a more effective monitoring of the gas levels available in the unit.

The system consists of a high-tech platform where integration with the hospital's current system takes place, connecting it to a database that will be powered by the programmable microelectronic device attached to a pressure gauge (Figure 5) used to measure pressure. This communication will be established through a wireless network of the wireless type, but if the location does not have internet, a global system for mobile GSM communications will be used, like that used by conventional cellular devices. The frame was printed on a 3D printer (Figures 4 and 5) using ABS polymer. The technology is not only limited to the healthcare system, it can also be used in the industry for gas control. 


\subsection{Component Descriptions}

\subsubsection{Esp8266 Esp-01}

The ESP8266 Module is an IOT device that consists of a 32-bit ARM microprocessor with built-in support for the WiFi network and integrated flash memory. This architecture allows it to be programmed independently, without the need for other microcontroller boards such as Arduino, for example [2].

\subsubsection{GSM module}

The SIM800L Module is used for communication via GSM / GPRS data, it needs a mobile phone operator chip for communication, the module can have its actions controlled by several types of microcontrollers, such as Arduino for example. To use it, you will need to weld the pins. Welding needs to be done well for the product to work properly. Solder resin residues can compromise the communication and energization of the plate [3].

\subsubsection{Digital pressure gauge}

The industrial digital manometer is an accessory used to measure the pressure of fluids and gases. Useful in industrial processes that require high performance and easy measurement visualization, the industrial digital manometer can be applied in the chemical, pharmaceutical, petrochemical, food, and mining industries. Being a modern equipment of the segment, the industrial digital manometer is ideal for the industry in general and works from its own digital meter with indicator [4].

\subsubsection{Power Supply}

According to Nilson and Riedel (2009) an electrical source is a device capable of converting non-electrical energy into electrical energy and vice versa. When a battery is discharged, it converts chemical energy into electrical energy, whereas when it is charged, it converts electrical energy into chemical energy [5].

\subsection{API}

API is a set of definitions and protocols used in the development and integration of application software. API is an English acronym that stands for application programming interface.

An API allows your solution or service to communicate with other products and services without having to know how they were implemented. This simplifies 
application development, saving time and money. When developing new tools and solutions (or managing existing ones), APIs offer the flexibility needed to simplify design, administration, and use, as well as providing opportunities for innovation [6].

Hermiz is an automatic control API, initially developed with the objective of managing oxygen cylinders in hospitals for greater control of resources. It integrates with other platforms (Figures 2 and 3 ) to facilitate the user's understanding.

It can also be used in the industrial area with other materials undergoing only a few changes

\subsection{Illustrations}

Figure 1. HERMIZ API - Administrative

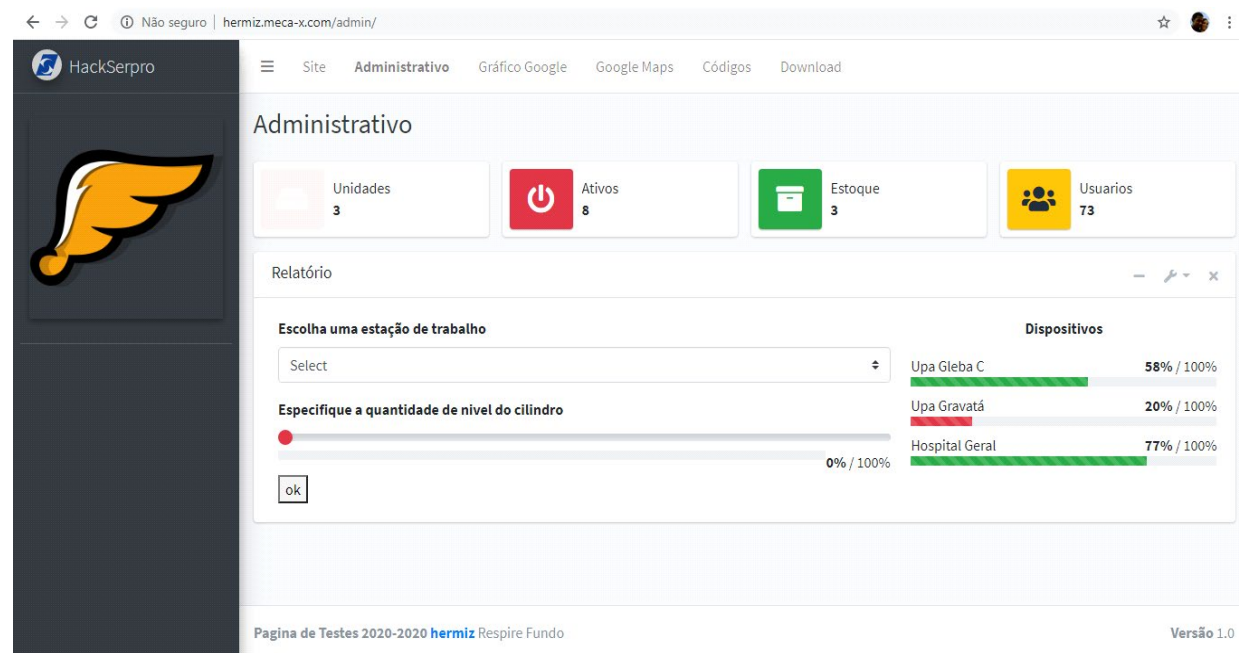

Figure 2. HERMIZ API - graphic integration

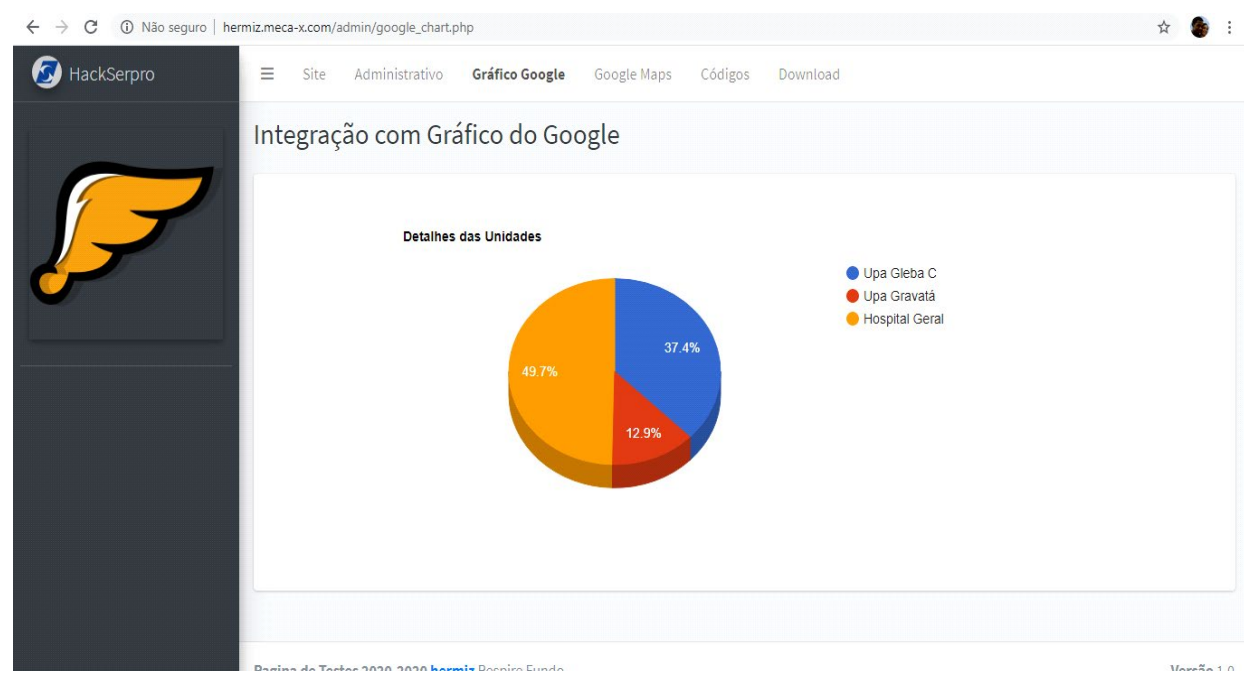


Figure 3. API HERMIZ - Maps integration

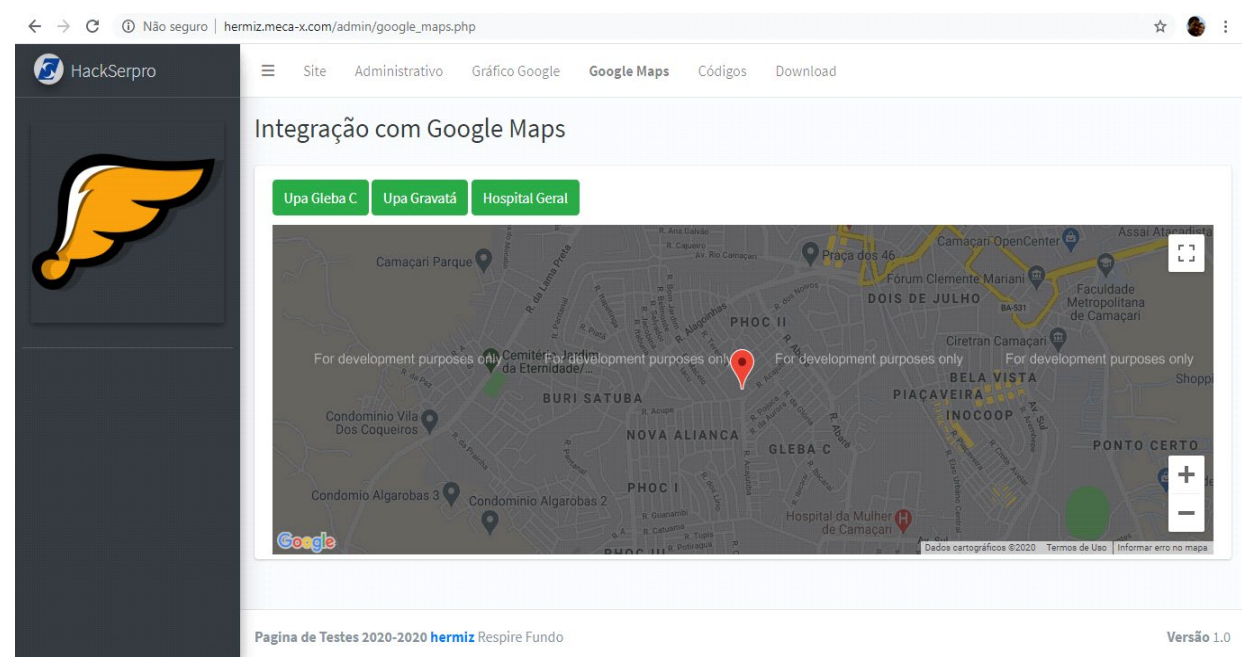

Figure 4. 3D MODELING OF THE FRAME

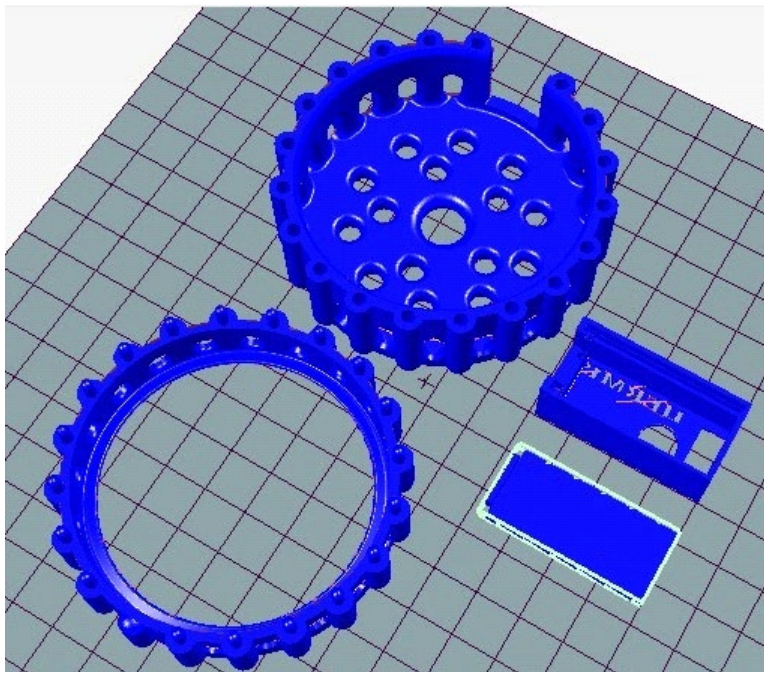

Figure 5. HARDWARE

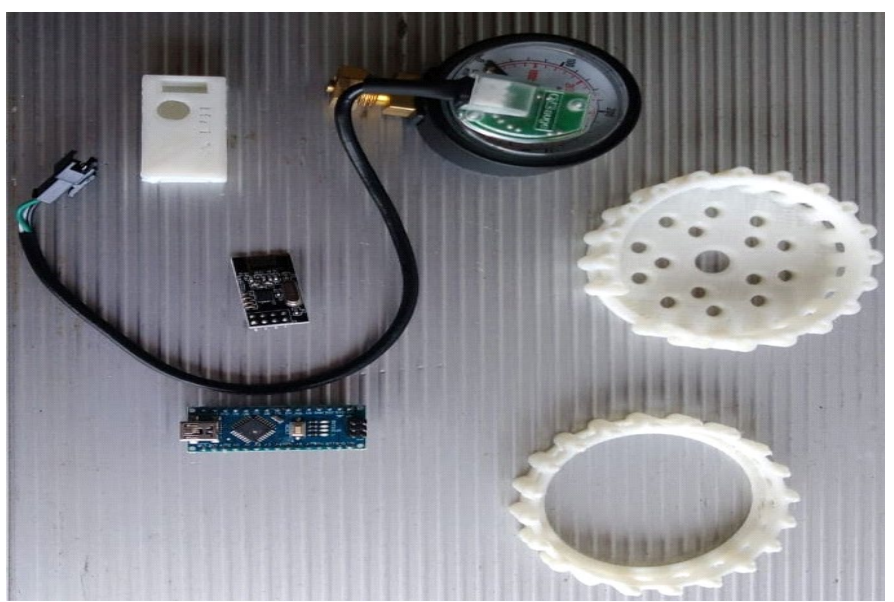




\section{RESULTS AND DISCUSSION}

From a field research carried out with some health professionals, it was found that the developed API solves several problems they face with patients who need to undergo respiratory therapies. It can be deployed on any existing web platform, bringing greater comfort to the user, where the user can access it in real time by both the computer and his smartphone, using a technology that combines hardware and software, as well as a solution IOT and with the data collected it allows the user a statistical predictability of gas consumption. The device is fast to produce and has a low cost.

\section{CONCLUSION}

The development of the device enabled the use of industry 4.0 technologies in the health area with simple solutions to problems that were causing a great impact due to the pandemic. Because it is capable of being used with any type of gas, the range of application possibilities is quite wide, and can cover the entire industrial sector.

\section{REFERENCES}

${ }^{1}$ BUSINESS, EPOCA. In the interior of Amazonas, pandemic zeroes oxygen supply and exposes indigenous people to infected workers. Available at <https://epocanegocios.globo.com/Brasil/noticia/2020/05/no-interior-do-amazonaspandemia-zera-estoque-de-oxigenio-e-expoe-indigenas-trabalhadoresinfectados.html />. Accessed on: July 1. 2020.

${ }^{2}$ BLOG MASTER WALKER SHOP. How to use with Arduino - ESP8266 ESP$01 \mathrm{WiFi}$ Module. Available at <https://blogmasterwalkershop.com.br/arduino/comousar-com-arduino-modulo-wifi-esp8266-esp-01/>. Accessed on: July 282020.

${ }^{3}$ ELETROGATE. GSM GPRS SIM800L module. Available at: <https://www.eletrogate.com/modulo-gsm-gprs-sim800I/> Accessed on: 28 Jul. 2020.

${ }^{4}$ WILLTEC. Industrial digital pressure gauge. Available at $<$ https://www.willtec.com.br/manometro-digital-industrial/>. Accessed on: July 28 2020.

${ }^{5}$ NILSSON, J. W; RIEDEL, SA; Electric circuits. Translation by Arlete Sinille Marques. 8. ed. Sao Paulo. 2009. Pearson Prentice Hall.

${ }^{6}$ HEDRAT. What is API ?. Available at <https://www.redhat.com/ptbr/topics/api/what-are-application-programming-interfaces>. Accessed on: July 28 2020. 